\title{
Taxonomic Study of Aromatic-Degrading Bacteria from Deep- Terrestrial-Subsurface Sediments and Description of Sphingomonas aromaticivorans sp. nov., Sphingomonas subterranea sp. nov., and Sphingomonas stygia sp. nov.
}

\author{
DAVID L. BALKWILL, ${ }^{1 *}$ GWENDOLYN R. DRAKE ${ }^{1}$ ROBERT H. REEVES, ${ }^{1}$ JAMES K. FREDRICKSON ${ }^{2}$ \\ DAVID C. WHITE,${ }^{3,4}$ DAVID B. RINGELBERG,${ }^{3}$ DARRELL P. CHANDLER, ${ }^{2}$ MARGARET F. ROMINE, ${ }^{2}$ \\ DAVID W. KENNEDY, ${ }^{2}$ AND CHRISTINA M. SPADONI ${ }^{2}$ \\ Department of Biological Science, Florida State University, Tallahassee, Florida 32306-3043 ${ }^{1}$; Pacific Northwest \\ National Laboratory, Richland, Washington 99352²; Center for Environmental Biotechnology, University \\ of Tennessee, Knoxville, Tennessee 37932-25673; and Environmental Sciences Division, \\ Oak Ridge National Laboratory, Oak Ridge, Tennessee $37831^{4}$
}

\begin{abstract}
Phylogenetic analyses of 16S rRNA gene sequences by distance matrix and parsimony methods indicated that six strains of bacteria isolated from deep saturated Atlantic coastal plain sediments were closely related to the genus Sphingomonas. Five of the strains clustered with, but were distinct from, Sphingomonas capsulata, whereas the sixth strain was most closely related to Blastobacter natatorius. The five strains that clustered with $S$. capsulata, all of which could degrade aromatic compounds, were gram-negative, non-spore-forming, nonmotile, rod-shaped organisms that produced small, yellow colonies on complex media. Their $\mathbf{G}+\mathrm{C}$ contents ranged from 60.0 to $65.4 \mathrm{~mol} \%$, and the predominant isoprenoid quinone was ubiquinone Q-10. All of the strains were aerobic and catalase positive. Indole, urease, and arginine dihydrolase were not produced. Gelatin was not liquified, and glucose was not fermented. Sphingolipids were present in all strains; 2OH14:0 was the major hydroxy fatty acid, and 18:1 was a major constituent of cellular lipids. Acid was produced oxidatively from pentoses, hexoses, and disaccharides, but not from polyalcohols and indole. All of these characteristics indicate that the five aromatic-degrading strains should be placed in the genus Sphingomonas as currently defined. Phylogenetic analysis of 16S rRNA gene sequences, DNA-DNA reassociation values, BOX-PCR genomic fingerprinting, differences in cellular lipid composition, and differences in physiological traits all indicated that the five strains represent three previously undescribed Sphingomonas species. Therefore, we propose the following new species: Sphingomonas aromaticivorans (type strain, SMCC F199), Sphingomonas subterranea (type strain, SMCC B0478), and Sphingomonas stygia (type strain, SMCC B0712).
\end{abstract}

Bacteria inhabit deep subsurface rocks and sediments and can influence the geochemistry of their surrounding environment $(9,19,43,45,51)$. Preliminary physiological studies of isolates obtained from deep Atlantic coastal plain sediments in the United States suggested that the subsurface bacterial populations in those sediments are metabolically diverse $(2,4,23)$. However, only limited efforts have been made to examine the phylogenetic traits of these isolates or to determine their taxonomic status $(7,46)$.

Because of the potential for in situ biodegradation of petroleum hydrocarbons in contaminated groundwater (i.e., bioremediation), there is considerable interest in bacteria that can degrade these compounds. One such organism, strain F199 ( $\mathrm{T}=$ type strain), was among the isolates obtained from deep Atlantic coastal plain sediments mentioned above and was found to degrade a broad range of aromatic compounds, including xylene, toluene, and naphthalene (18). The ability to degrade these compounds is encoded on a 180 -kb plasmid in F199 ${ }^{\mathrm{T}}$ (52), which may have evolved because sedimentary organic material is the principal source of energy in this organism's environment (18). Strain F199 ${ }^{\mathrm{T}}$ and several other subsurface bacterial isolates that can degrade various aromatic

\footnotetext{
* Corresponding author. Mailing address: Department of Biological Science, Florida State University, 312 Nuclear Research Building, Tallahassee, FL 32306-3043. Phone: (904) 644-5719. Fax: (904) 644-4865. E-mail: balkwill@bio.fsu.edu.
}

compounds were subsequently shown to be members of the genus Sphingomonas (16).

The genus Sphingomonas was described by Yabuuchi et al. (64) and later was emended by Takeuchi et al. (55). Organisms in this genus are gram-negative, non-spore-forming rods that have a single polar flagellum when they are motile. They are yellow and obligately aerobic and produce catalase. Acid is produced oxidatively from pentoses, hexoses, and disaccharides, but not from polyalcohols and inulin. The major respiratory quinone is ubiquinone Q-10, and the major fatty acids of the cellular lipid are 18:1 and 2OH14:0. The cellular lipid contains sphingoglycolipid. The $\mathrm{G}+\mathrm{C}$ contents of the genomic DNAs range from 61.6 to $67.8 \mathrm{~mol} \%$.

The genus Sphingomonas appears to be ubiquitous in soil, water, and sediments. Sphingomonas strains isolated from these environments have broad catabolic capabilities and, therefore, have high potential for bioremediation and waste treatment. Among the contaminants that can be degraded by various Sphingomonas species are dibenzo- $p$-dioxin and dibenzofuran (63); hexachlorocyclohexane (25); chlorinated biphenyls (54); pentachlorophenol (29); halogenated diphenyl ethers (48); naphthalenesulfonic acids (33); toluene, naphthalene, and xylene (18); and polyaromatic hydrocarbons $(31,42)$. Of the aromatic-degrading Sphingomonas strains described to date, Sphingomonas yanoikuyae B1 has been studied most extensively at the biochemical and molecular levels. A recent genetic homology study (32) showed that the genes for biphenyl and $m$-xylene degradation in this strain were similar to the genes in 
another surface soil isolate (S. yanoikuyae Q1) and five deepsubsurface strains $\left(\mathrm{F} 199^{\mathrm{T}}, \mathrm{B} 0522, \mathrm{~B} 0695, \mathrm{~B} 0478^{\mathrm{T}}\right.$, and $\mathrm{B} 0712^{\mathrm{T}}$ ). However, the degradative genes in the surface strains were located on the chromosome, whereas the degradative genes in the subsurface strains were located on plasmids.

In this study, we describe the morphological, biochemical, and phylogenetic characteristics of aromatic-degrading subsurface Sphingomonas strains isolated from deep Atlantic coastal plain sediments. We also propose that five of the subsurface strains be assigned to three new species of Sphingomonas, Sphingomonas aromaticivorans sp. nov., Sphingomonas subterranea sp. nov., and Sphingomonas stygia sp. nov.

\section{MATERIALS AND METHODS}

Sources of bacterial strains and maintenance of cultures. Sphingomonas cap sulata ATCC 14666, Sphingomonas paucimobilis ATCC 29837, and S. yanoikuyae ATCC 51230 were obtained from the American Type Culture Collection. $S$. yanoikuyae $\mathrm{B} 1$ and $\mathrm{Q} 1$ (see references 31 and 32 were obtained from Gerben J. Zylstra (Rutgers University, New Brunswick, N.J.). The subsurface bacterial strains used in this study (B0477, B0478 ${ }^{\mathrm{T}}, \mathrm{B} 0522, \mathrm{~B} 0695, \mathrm{~B} 0712^{\mathrm{T}}$, and $\mathrm{F} 199^{\mathrm{T}}$ ) which were isolated from deep saturated Atlantic coastal plain sediments $(2,17)$ were obtained from the Department of Energy (DOE) Subsurface Microbial Culture Collection (SMCC) at Florida State University (3). All strains were cultured on $1 \%$ PTYG medium (5) and were maintained as described previously (16). For $\mathrm{G}+\mathrm{C}$ content analyses, bacteria were grown in half-strength Luria broth at $30^{\circ} \mathrm{C}$ with rotary shaking; $100-\mathrm{ml}$ cultures were inoculated from single colonies (grown on $0.5 \times$ Luria broth agar), incubated overnight, and transferred to 1 liter of fresh medium. The cultures were incubated at $30^{\circ} \mathrm{C}$ for 2 days and then harvested by centrifugation.

Microscopy. Gram staining was performed by the Hucker method (12). Capsule staining was performed by the India ink method (12).

Physiological characterization. Selected physiological traits of $S$. capsulata, $S$ paucimobilis, and the subsurface strains were determined with API NFT (nine metabolic capabilities and aerobic growth on 12 carbon sources), API $50 \mathrm{CH}$ (utilization of and oxidative acid production from 49 carbohydrates and related compounds), and API ZYM (19 enzymatic activities) test kits (bioMérieuxVitek, Inc., Hazelwood, Mo.). All API tests were performed in accordance with the manufacturer's directions. Fermentative acid production and oxidative acid production from 25 carbohydrates were tested by growth in OF basal medium (Difco Laboratories, Detroit, Mich.) (soft-agar stabs with and without sterile mineral oil overlay, respectively) supplemented with 0.5 to $1 \%$ carbohydrate. The $\mathrm{OF}$ medium tubes were incubated at $30^{\circ} \mathrm{C}$ for 10 days, during which reactions were recorded every 2 days.

Phylogenetic analysis. Genomic DNAs were isolated from $S$. paucimobilis ATCC 29837 and the subsurface strains by a standard chloroform-isoamyl alcohol extraction procedure (26). Twenty nanograms of DNA was then used as a template for PCR amplification (47) of an approximately 1,500-base segment of the $16 \mathrm{~S}$ rRNA gene (i.e., nearly the entire gene). The PCR amplification primers used were primers fD1 (AGAGTTTGATCCTGGCTCAG) and rP2 (ACGGC TACCTTGTTACGACTT) (62).

The PCR amplification products were sequenced with an Applied Biosystems model 373A DNA sequencer by using the Taq DyeDeoxy terminator cycle sequencing method $(1,39)$. The following primers were used to sequence all six strains: primer C (ACGGGCGGTGTGTAC), corresponding to positions 1406 to 1392 in the $16 \mathrm{~S}$ ribosomal DNA (rDNA) nucleotide sequence of Escherichia coli (8); primer H (ACACGAGCTGACGACAGCCA; E. coli positions 1075 to 1056 ); primer G (CCAGGGTATCTAATCCTGTT; $E$. coli positions 800 to 781 ) primer A (GTATTACCGCGG[C/G]TGCTG; E. coli positions 536 to 519); and primer P (CTGCTGCCTCCCGTAGGAG; E. coli positions 357 to 339). One or more the following complementary primers were used as needed (to resolve ambiguous bases or to obtain additional information) for sequencing of some strains: primers $\mathrm{F}_{2} \mathrm{C}$ (AGAGTTTGATC[A/C]TGGCTC; positions 8 to 25), PC (CTACGGGAGGCAGCAG; positions 342 to 357), AC (CAGCCGCGGTAA TAC; positions 522 to 536), GC (AACAGGATTAGATACCCTGG; positions 781 to 800 ), and HC (TGGCTGTCGTCAGCTCGTGT; positions 1056 to 1075) Primers A and C were described by Lane et al. (34), and primers $P$ and $P C$ were described (as primers 339-357 and 357-342, respectively) by Weisburg et al. (62) The remaining primers were developed by R. H. Reeves and J. Y. Reeves at Florida State University. The resulting sequences were assembled to produce 1,304-base contiguous rDNA sequences corresponding to $E$. coli positions 30 to 1375. Between 70 and $85 \%$ of the contiguous sequences for each strain could be read from more than one primer during assembly.

A previous analysis of the 16S rRNA gene sequences of strains $F 199^{\mathrm{T}}$ and B0695 (16) indicated that these organisms fall in the alpha subclass of the Proteobacteria and are probably members of the genus Sphingomonas $(55,64)$. To more precisely determine the phylogenetic position of these strains and the other subsurface strains within the genus Sphingomonas in the present study, their $16 \mathrm{~S}$ rDNA sequences were hand aligned with the corresponding sequences for 54 selected strains of eubacteria (Table 1). Included in this alignment were (i) all of the Sphingomonas sequences (including more than 150 bases) currently available from GenBank, the European Molecular Biology Laboratory (EMBL) database, and the Ribosomal Database Project (RDP), version 5 (36); (ii) sequences of 11 species belonging to the alpha subclass of the Proteobacteria and closely related to the genus Sphingomonas; and (iii) an Arthrobacter globiformis sequence (which was used as an outgroup). The aligned sequences were then analyzed by parsimony and distance matrix methods (see below). This analysis was limited to three regions (corresponding to $E$. coli positions 227 to 501,720 to 894 , and 1180 to 1375; a total of approximately 622 bases) for which sequences were available for all 60 strains in the alignment set (including the subsurface strains).

Based on the phylogenetic trees produced by the analyses described above (data not shown), 41 sequences were selected for an analysis of a more complete portion of the 16S rRNA gene. This alignment set included the sequences of the subsurface strains, 24 representative Sphingomonas strains (including the strains that were most closely related to the subsurface strains according to the analysis described above), 10 representative species belonging to the alpha subclass of the Proteobacteria, and $A$. globiformis (used as the outgroup). The aligned sequences were analyzed with parsimony and distance matrix methods (see below). This analysis included a region corresponding to $E$. coli positions 30 to 1375 , from which a few small segments of sequence were excluded because the alignment was ambiguous in those regions. (A total of 1,292 bases were retained for analysis.)

Maximum-parsimony analysis was performed with the program Phylogenetic Analysis Using Parsimony, Macintosh version 3.1.1 (PAUP) (53). Only the phylogenetically informative sites were considered. A heuristic search was carried out first (by using the standard program defaults), after which a bootstrap analysis was used to evaluate the branch points of the resulting phylogenetic trees. Consensus phylogenetic trees were produced by bootstrapping at the greater-than-50\% confidence limit, with 100 replications (13).

The distance matrix analysis was carried out by using the PHYLIP package of computer programs (14). Distances were calculated by the method of Jukes and Cantor (28), after which phylogenies were estimated with the FITCH option (which makes use of the Fitch-Margoliash criterion [15] and some related leastsquares criteria).

BOX-PCR genomic fingerprinting. For repetitive DNA PCR fingerprinting we used the BOX A repetitive element originally described by Martin et al. (37). BOX fingerprints were generated by using 30 to $40 \mathrm{ng}$ of genomic DNA and the methods described by Louws et al. (35). The BOX A1R primer (CTACGG CAAGGCGACGCTGACG) was synthesized by Keystone Laboratories, Inc. Menlo Park, Calif., and was used in $50-\mu l$ PCR mixtures containing $10 \mathrm{mM}$ Tris- $\mathrm{HCl}\left(\mathrm{pH} 8.3\right.$ ), $50 \mathrm{mM} \mathrm{KCl}, 1.5 \mathrm{mM} \mathrm{MgCl}_{2}, 10 \%$ dimethyl sulfoxide, each deoxynucleoside triphosphate at a concentration of $200 \mu \mathrm{M}, 0.2 \mu \mathrm{M}$ BOX A1R primer, and $1.25 \mathrm{U}$ of LD-Taq (Perkin-Elmer) in a Perkin-Elmer model 9600 thermal cycler. The genomic DNA, primer, and dimethyl sulfoxide were hotstarted at $80^{\circ} \mathrm{C}$ before the Taq-buffer-deoxynucleoside triphosphate mixture was added. The PCR protocol included an initial denaturation step for $2 \mathrm{~min}$ at $94^{\circ} \mathrm{C}$ 30 reaction cycles $\left(94^{\circ} \mathrm{C}\right.$ for $15 \mathrm{~s}, 52^{\circ} \mathrm{C}$ for $15 \mathrm{~s}$, and $65^{\circ} \mathrm{C}$ for $6 \mathrm{~min}$, with a 5 -s extension), and a final 20 -min extension step at $65^{\circ} \mathrm{C}$ prior to soaking at $4^{\circ} \mathrm{C}$. Thirty microliters of the amplification products was analyzed by agarose $(1.5 \%)$ gel electrophoresis in TAE buffer ( $40 \mathrm{mM}$ Tris-acetate, 2 mM EDTA).

DNA-DNA hybridization. The general approaches used for DNA-DNA hybridization have been described elsewhere (27). Briefly, genomic DNA from each strain was prepared for blotting by shearing in a French press at 16,000 $\mathrm{lb} / \mathrm{in}^{2}$. Approximately $0.5 \mu \mathrm{g}$ of DNA was blotted onto a nylon membrane (Boehringer-Mannheim, Indianapolis, Ind.) by using a dot blot manifold (Schleicher and Schuell) and methods suggested by the manufacturer. Additional DNA from each strain was labeled to a high specific activity $\left(>10^{8} \mathrm{dpm} / \mu \mathrm{g}\right)$ with ${ }^{32} \mathrm{P}$ (by using a Prime-It II random primer labeling kit [Stratagene, La Jolla, Calif.]) and used to probe the immobilized DNA samples on the membranes. Hybridizations were conducted at $70^{\circ} \mathrm{C}$ in $6 \times \mathrm{SSC}(1 \times \mathrm{SSC}$ is $0.16 \mathrm{M} \mathrm{NaCl}$ plus 0.015 M sodium citrate, $\mathrm{pH} 7.0$ ) containing Denhardt's solution (10) overnight. The membranes were then washed twice with $2 \times \mathrm{SSC}-0.1 \%$ sodium dodecyl sulfate (SDS) for $5 \mathrm{~min}$ at room temperature, once with $0.1 \times \mathrm{SSC}-0.1 \%$ SDS for $15 \mathrm{~min}$ at $70^{\circ} \mathrm{C}$, and once with $2 \times \mathrm{SSC}$ at room temperature. After blotting to remove excess liquid, the radioactivity associated with the individual sample areas on the dot blots was counted by using a Top Count microplate scintillation counter (Packard Instrument Co., Meriden, Conn.). Each hybridization value represents the mean of three replicates. The average range of variation was $\pm 4 \%$.

$\mathbf{G}+\mathbf{C}$ content of DNA. The $\mathrm{G}+\mathrm{C}$ contents of the Sphingomonas isolates were determined as described by Mesbah and Whitman (40). Analyses were performed with a series II 1090 liquid chromatograph (Hewlett-Packard, Avondale, $\mathrm{Pa}$.) fitted with an Alltech Econosphere $\mathrm{C}_{18}$ reversed-phase column $(250 \mathrm{~mm}$ by $4.6 \mathrm{~mm}$ [inside diameter]; particle size, $0.5 \mu \mathrm{m}$; Alltech Associates, Inc., Deerfield, Ill.). The mobile phase was $20 \mathrm{mM}$ triethylamine phosphate (pH 5.1) in $12 \%$ methanol. The flow rate was $1 \mathrm{ml} / \mathrm{min}$, and the column temperature was $37^{\circ} \mathrm{C}$. Nonmethylated lambda phage DNA $(500 \mu \mathrm{g} / \mathrm{ml}$; Sigma) with a known molar ratio of $\mathrm{dT}$ to $\mathrm{dG}$ was used as a standard. Each reported value represents the mean of five determinations. The standard deviations ranged from 0.23 to $0.93 \mathrm{~mol} \% \mathrm{G}+\mathrm{C}$, and the average standard deviation was $0.52 \mathrm{~mol} \% \mathrm{G}+\mathrm{C}$

Fatty acid analyses. Analysis of fatty acids was performed as described by Guckert et al. (22). Nutrient broth (BBL) cultures $(500 \mathrm{ml})$ of the various 
TABLE 1. Strains included in phylogenetic analysis of 16S rRNA gene sequences

\begin{tabular}{|c|c|c|c|c|c|c|}
\hline Taxon & $\begin{array}{l}\text { Other (former) } \\
\text { designation(s) }\end{array}$ & $\begin{array}{l}\text { Culture collection } \\
\text { accession no. }\end{array}$ & $\begin{array}{l}\text { Original source } \\
\text { of strain }\end{array}$ & $\begin{array}{l}\text { Source of } \\
\text { sequence }\end{array}$ & $\begin{array}{l}\text { EMBL and/or } \\
\text { GenBank ac- } \\
\text { cession no. }\end{array}$ & $\begin{array}{l}\text { Refer- } \\
\text { ence }\end{array}$ \\
\hline Arthrobacter globiformis & & DSM 20124 & & RDP & M23411 & \\
\hline Blastobacter natatorius & & & & RDP & X73043 & 24 \\
\hline Brevundimonas diminuta & $\begin{array}{l}\text { (Pseudomonas diminuta type } \\
\text { strain) }\end{array}$ & $\begin{array}{r}\text { ATCC } 11568^{\mathrm{T}}\left(=\text { CCEB } 513^{\mathrm{T}}=\right. \\
\left.\text { CCUG } 1427^{\mathrm{T}}=\operatorname{LMG~} 1793^{\mathrm{T}}\right)\end{array}$ & & RDP & M59064 & \\
\hline Caulobacter subvibrioides & Strain CB81 & & & RDP & M83797 & 50 \\
\hline Erythrobacter longus & Strain Och 101 & $\operatorname{ATCC} 33941^{\mathrm{T}}\left(=\right.$ IFO $\left.14126^{\mathrm{T}}\right)$ & & RDP & M59062 & \\
\hline Erythromicrobium ramosum & $\begin{array}{l}\text { Strain E5 Yurkov }{ }^{\mathrm{T}} \text {, strain } \\
\text { Drews }^{\mathrm{T}}\end{array}$ & DSM $8510^{\top}$ & & RDP & X72909 & 65 \\
\hline Hyphomonas jannaschiana & Strain VP-1 & ATCC 33882 & & RDP & M83806 & 50 \\
\hline Porphyrobacter neustonensis & & ACM 2844 & & RDP & M96745 & 20 \\
\hline Pseudomonas mendocina & & ATCC $25411^{\mathrm{T}}$ & & RDP & M59154 & \\
\hline Rhizomonas suberifaciens & & IFO $15211^{\mathrm{T}}$ & & RDP & D13737 & 56 \\
\hline Rhodospirillum salexigens & & DSM $2132(=$ ATCC 35888$)$ & & $\mathrm{RDP}$ & M59070 & \\
\hline Sphingomonas adhaesiva & $\begin{array}{l}\text { (Pseudomonas paucimobilis } \\
\text { Op- } 55^{\mathrm{T}} \text { ) }\end{array}$ & $\begin{array}{l}\text { GIFU } 11458^{\mathrm{T}}\left(=\text { IFO } 15099^{\mathrm{T}}\right. \\
\left.\quad=\text { JCM } 7370^{\mathrm{T}}\right)\end{array}$ & "Sterile" water & RDP & D16146 & 64 \\
\hline Sphingomonas adhaesiva & $\begin{array}{l}\text { (Pseudomonas paucimobilis } \\
\text { Op- } 55^{\mathrm{T}} \text { ) }\end{array}$ & $\begin{array}{l}\text { JCM } 7370^{\mathrm{T}}\left(=\text { IFO } 15099^{\mathrm{T}}=\right. \\
\left.\text { GIFU } 11458^{\mathrm{T}}\right)\end{array}$ & "Sterile" water & RDP & $\mathrm{X} 72720$ & 41 \\
\hline Sphingomonas adhaesiva & $\begin{array}{l}\text { (Pseudomonas paucimobilis } \\
\text { Op-55 } 5 \text { ) }\end{array}$ & $\begin{array}{l}\text { IFO } 15099^{\mathrm{T}}\left(=\text { GIFU } 11458^{\mathrm{T}}\right. \\
\left.=\text { JCM } 7370^{\mathrm{T}}\right)\end{array}$ & "Sterile" water & RDP & D13722 & 55 \\
\hline Sphingomonas asaccharolytica & $\mathrm{Y}-345^{\mathrm{T}}$ & IFO $15499^{\mathrm{T}}$ & Plant roots & GenBank & D28571-D28573 & 56 \\
\hline Sphingomonas capsulata & $\begin{array}{l}\text { (Flavobacterium capsulatum } \\
\text { type strain) }\end{array}$ & $\begin{array}{l}\text { GIFU } 11526^{\mathrm{T}}\left(=\text { IFO } 12533^{\mathrm{T}}\right. \\
=\text { JCM } 7508^{\mathrm{T}}=\text { ATCC } \\
14666^{\mathrm{T}}={\text { DSM } 31096^{\mathrm{T}}=}^{\left.\text {NCIB } 9890^{\mathrm{T}}\right)}\end{array}$ & Distilled water & RDP & D16147 & 64 \\
\hline Sphingomonas capsulata & $\begin{array}{l}\text { (Flavobacterium capsulatum } \\
\text { type strain) }\end{array}$ & $\begin{array}{l}\text { ATCC } 14666^{\mathrm{T}}(=\text { GIFU } \\
11526^{\mathrm{T}}=\text { IFO } 12533^{\mathrm{T}}= \\
\text { JCM } 7508^{\mathrm{T}}=\text { DSM } 31096^{\mathrm{T}} \\
\left.=\text { NCIB } 9890^{\mathrm{T}}\right)\end{array}$ & Distilled water & RDP & & \\
\hline Sphingomonas macrogoltabidus & (Flavobacterium sp.) & IFO $15033^{\mathrm{T}}\left(=\right.$ ATCC $\left.51380^{\mathrm{T}}\right)$ & & RDP & D13723 & 55 \\
\hline Sphingomonas mali & $\mathrm{Y}-347^{\mathrm{T}}$ & IFO $15500^{\mathrm{T}}$ & Plant roots & GenBank & D28574-D28576 & 56 \\
\hline Sphingomonas parapaucimobilis & $\begin{array}{l}\text { (Pseudomonas paucimobilis } \\
\mathrm{OH} 3807 \text { ) }\end{array}$ & $\begin{array}{l}\text { IFO } 15100^{\mathrm{T}}\left(=\text { JCM } 7510^{\mathrm{T}}=\right. \\
\left.\quad \text { GIFU } 11387^{\mathrm{T}}\right)\end{array}$ & Urine & RDP & D13724 & 55 \\
\hline Sphingomonas parapaucimobilis & $\begin{array}{l}\text { (Pseudomonas paucimobilis } \\
\mathrm{OH} 3807 \text { ) }\end{array}$ & $\begin{array}{l}\text { JCM } 7510^{\mathrm{T}}\left(=\text { IFO } 15100^{\mathrm{T}}=\right. \\
\left.\text { GIFU } 11387^{\mathrm{T}}\right)\end{array}$ & Urine & RDP & $X 72721$ & 41 \\
\hline Sphingomonas paucimobilis & (Pseudomonas paucimobilis) & $\begin{array}{l}\text { IFO } 13935^{\mathrm{T}}\left(=\text { JCM } 7516^{\mathrm{T}}=\right. \\
\text { GIFU } 2395^{\mathrm{T}}=\text { ATCC } \\
\left.29837^{\mathrm{T}}=\text { NCTC } 11030^{\mathrm{T}}\right)\end{array}$ & Respirator & RDP & D13725 & 55 \\
\hline Sphingomonas paucimobilis & (Pseudomonas paucimobilis) & $\begin{array}{l}\text { GIFU } 2395^{\mathrm{T}}\left(=\text { IFO } 13935^{\mathrm{T}}\right. \\
=\mathrm{JCM} 7516^{\mathrm{T}}=\text { ATCC } \\
\left.29837^{\mathrm{T}}=\text { NCTC } 11030^{\mathrm{T}}\right)\end{array}$ & Respirator & RDP & D16144 & 64 \\
\hline Sphingomonas paucimobilis & (Pseudomonas paucimobilis) & $\begin{array}{l}\text { ATCC } 29837^{\mathrm{T}}\left(=\mathrm{IFO} 13935^{\mathrm{T}}\right. \\
=\mathrm{JCM} 7516^{\mathrm{T}}=\mathrm{GIFU} \\
\left.2395^{\mathrm{T}}=\text { NCTC } 11030^{\mathrm{T}}\right)\end{array}$ & Respirator & GenBank & U20776 & 16 \\
\hline Sphingomonas paucimobilis & (Pseudomonas paucimobilis) & $\begin{array}{l}\text { ATCC } 29837^{\mathrm{T}}\left(=\mathrm{IFO} 13935^{\mathrm{T}}\right. \\
=\mathrm{JCM} 7516^{\mathrm{T}}=\mathrm{GIFU} \\
\left.2395^{\mathrm{T}}=\text { NCTC } 11030^{\mathrm{T}}\right)\end{array}$ & Respirator & GenBank & U37337 & \\
\hline Sphingomonas paucimobilis & $\begin{array}{l}\text { (Flavobacterium devorans type } \\
\text { strain) }\end{array}$ & $\begin{array}{l}\text { ATCC } 10829(=\text { NRRL B-54 } \\
=\text { GIFU } 1367=\text { JCM } 7511)\end{array}$ & Not recorded & RDP & & \\
\hline Sphingomonas paucimobilis & Strain EPA 505 & & & GenBank & X94100 & \\
\hline Sphingomonas paucimobilis & Strain EPA 505 & & & GenBank & U37341 & \\
\hline Sphingomonas pruni & $\mathrm{Y}-250^{\mathrm{T}}$ & IFO $15498^{\mathrm{T}}$ & Plant roots & GenBank & D28568-D28570 & 56 \\
\hline Sphingomonas rosa & (Agrobacterium rhizogenes) & $\begin{array}{l}\text { IAM } 14222^{\mathrm{T}}\left(=\text { IFO } 15208^{\mathrm{T}}\right. \\
\left.=\text { NCPPB } 2661^{\mathrm{T}}\right)\end{array}$ & Plant roots & GenBank & D13945 & 56 \\
\hline Sphingomonas sanguis & $\begin{array}{l}\text { (Sphingomonas genospecies } 1 \\
\text { Pseudomonas paucimobilis) }\end{array}$ & $\begin{array}{l}\text { IFO } 13937^{\mathrm{T}}\left(=\text { JCM } 7514^{\mathrm{T}}=\right. \\
\left.\text { GIFU } 2397^{\mathrm{T}}=\text { NCTC } 11032^{\mathrm{T}}\right)\end{array}$ & Blood & RDP & D13726 & 55 \\
\hline Sphingomonas subarctica & Strain KF1 (Pseudomonas sp.) & & & GenBank & X94102 & $44 a$ \\
\hline Sphingomonas subarctica & Strain KF3 (Pseudomonas sp.) & & & GenBank & X94103 & \\
\hline Sphingomonas subarctica & Strain NKF1 (Pseudomonas sp.) & & & GenBank & X94104 & \\
\hline Sphingomonas terrae & (Flavobacterium sp.) & IFO $15098^{\mathrm{T}}\left(=\mathrm{JCM} 7513^{\mathrm{T}}\right)$ & & RDP & D13727 & 55 \\
\hline Sphingomonas yanoikuyae & $\begin{array}{l}\text { (Sphingobacterium sp. strain } \\
\mathrm{AB} 1105^{\mathrm{T}} \text { ) }\end{array}$ & $\begin{array}{l}\text { IFO } 15102^{\mathrm{T}}\left(=\text { JCM } 7371^{\mathrm{T}}=\right. \\
\left.\text { GIFU } 9882^{\mathrm{T}}=\text { ATCC } 51230^{\mathrm{T}}\right)\end{array}$ & Clinical specimen & RDP & D13728 & 55 \\
\hline Sphingomonas yanoikuyae & $\begin{array}{l}\text { (Sphingobacterium sp. strain } \\
\text { AB } 1105^{\mathrm{T}} \text { ) }\end{array}$ & $\begin{aligned} \text { GIFU } 9882^{\mathrm{T}}( & =\text { IFO } 15102^{\mathrm{T}}= \\
\text { JCM } 7371^{\mathrm{T}} & \left.=\text { ATCC } 51230^{\mathrm{T}}\right)\end{aligned}$ & Clinical specimen & RDP & D16145 & 64 \\
\hline Sphingomonas yanoikuyae & $\begin{array}{l}\text { (Sphingobacterium sp. strain } \\
\quad \mathrm{AB} 1105^{\mathrm{T}} \text { ) }\end{array}$ & $\begin{array}{l}\text { JCM } 7371^{\mathrm{T}}\left(=\text { IFO } 15102^{\mathrm{T}}=\right. \\
\left.\text { GIFU } 2397^{\mathrm{T}}=\text { ATCC } 51230^{\mathrm{T}}\right)\end{array}$ & Clinical specimen & RDP & $X 72725$ & 41 \\
\hline Sphingomonas yanoikuyae & Strain B1 (PAH degrader) ${ }^{a}$ & & & GenBank & X85023 & 31 \\
\hline
\end{tabular}


TABLE $1-$ Continued

\begin{tabular}{|c|c|c|c|c|c|c|}
\hline Taxon & $\begin{array}{l}\text { Other (former) } \\
\text { designation(s) }\end{array}$ & $\begin{array}{l}\text { Culture collection } \\
\text { accession no. }\end{array}$ & $\begin{array}{l}\text { Original source } \\
\text { of strain }\end{array}$ & $\begin{array}{l}\text { Source of } \\
\text { sequence }\end{array}$ & $\begin{array}{c}\text { EMBL and/or } \\
\text { GenBank ac- } \\
\text { cession no. }\end{array}$ & $\begin{array}{l}\text { Refer- } \\
\text { ence }\end{array}$ \\
\hline Sphingomonas yanoikuyae & $\begin{array}{l}\text { Strain Q1 (Pseudomonas pauci- } \\
\quad \text { mobilis) }\end{array}$ & & & GenBank & U37525 & 60 \\
\hline Sphingomonas yanoikuyae & (Chromobacterium lividum) & $\begin{array}{l}\text { IAM } 14225(=\text { IFO } 15163= \\
\quad \text { NCTC } 10590)\end{array}$ & Plant roots & GenBank & D13946 & 56 \\
\hline Sphingomonas yanoikuyae & B1 (Beijerinckia sp. strain B1) & & & GenBank & U37524 & 60 \\
\hline Sphingomonas sp. & Strain B0477 & SMCC B0477 & Subsurface & GenBank & U20772 & \\
\hline Sphingomonas sp. & Strain $\mathrm{B} 0478^{\mathrm{T}}$ & $\mathrm{SMCC} \mathrm{B0478^{ \textrm {T } }}$ & Subsurface & GenBank & U20773 & \\
\hline Sphingomonas sp. & Strain B0522 & SMCC B0522 & Subsurface & GenBank & U20774 & \\
\hline Sphingomonas sp. & Strain B0695 & SMCC B0695 & Subsurface & GenBank & U20755 & \\
\hline Sphingomonas sp. & Strain $\mathrm{B} 0712^{\mathrm{T}}$ & $\mathrm{SMCC} \mathrm{B0712^{ \textrm {T } }}$ & Subsurface & GenBank & U20775 & \\
\hline Sphingomonas sp. & Strain F199 & SMCC F199 & Subsurface & GenBank & U20756 & \\
\hline Sphingomonas sp. & Strain A175 & & & GenBank & X94101 & \\
\hline Sphingomonas sp. & Strain B1 & & & GenBank & X94099 & \\
\hline Sphingomonas sp. & Strain BF14 (Blastobacter sp.) & & & RDP & $\mathrm{Z} 23157$ & 24 \\
\hline Sphingomonas sp. & Strain BN6 & & & GenBank & X94098 & \\
\hline Sphingomonas sp. & Strain RW1 & & River water & RDP & $X 72723$ & 41 \\
\hline Sphingomonas sp. & Strain SS86 & & & RDP & D16148 & \\
\hline Sphingomonas sp. & Strain SYK6 & & & RDP & D16149 & \\
\hline Sphingomonas sp. & Strain UN1F1 & & & GenBank & U37345 & \\
\hline Sphingomonas sp. & Strain UN1F2 & & & GenBank & U37346 & \\
\hline Sphingomonas sp. & Strain UN1P1 & & & GenBank & U37347 & \\
\hline Strain C7 (azo dye degrading) & (Pseudomonas paucimobilis) & & & RDP & L22759 & 21 \\
\hline Zymomonas mobilis & Z. mobilis subsp. mobilis & $\begin{array}{l}\text { ATCC } 10988^{\mathrm{T}}(=\text { NRRL } \\
\left.\text { B- } 806^{\mathrm{T}}=\text { NCI } 8938^{\mathrm{T}}\right)\end{array}$ & & RDP & & \\
\hline
\end{tabular}

"PAH, polycyclic aromatic hydrocarbon.

Sphingomonas strains were incubated at room temperature for 4 days, harvested by centrifugation, and lyophilized. After extraction by a modified Bligh-Dyer procedure (6), the total extractable lipid was divided in half. One-half was fractionated on a silicic acid column, from which the polar lipids were collected and transesterified into methyl ethers for gas chromatography (GC) analysis. The other half of the extractable lipid was subjected to $5 \% \mathrm{KOH}$ saponification (44). Fatty acid methyl esters were formed by using strong acid methanolysis. The residuc from the Bligh-Dyer procedure was subjected to acid hydrolysis and esterification similar to that described by Mayberry and Lane (38). The hydroxy fatty acids were derivatized with $N, O$-bis(trimethylsilyl)-trifluoroacetamide (BSTFA), which resulted in trimethylsilyl esters before analysis by GC. Mass spectral verification of all lipid moieties was accomplished by using a model HP5971 mass selective detector interfaced with a model HP5890 series II GC equipped with a Restek $\mathrm{Rt}_{\mathrm{x}}-1$ capillary column (length, $60 \mathrm{~m}$; inside diameter, 0.2 $\mathrm{mm}$; film thickness, $0.1 \mu \mathrm{m}$ ). The temperature program used for this analysis was as follows: the initial temperature was $100^{\circ} \mathrm{C}$, and the temperature was immediately increased at a rate of $10^{\circ} \mathrm{C} / \mathrm{min}$ to $150^{\circ} \mathrm{C}$, held at $150^{\circ} \mathrm{C}$ for $1 \mathrm{~min}$, and then increased at a rate of $3^{\circ} \mathrm{C} / \mathrm{min}$ to the final temperature, $280^{\circ} \mathrm{C}$, which was maintained for an additional $3 \mathrm{~min}$. The mass selective detector was run at $70 \mathrm{eV}$ by using positive ion electron impact ionization.

Sphingolipid analyses. Cells for sphingolipid analyses were obtained from the same lyophilized preparations as those used for phospholipid fatty acid analysis. Lipids from S. paucimobilis, S. capsulata, and strains B0477, B0478 ${ }^{\mathrm{T}}, \mathrm{B} 0522$, and $\mathrm{B} 0712^{\mathrm{T}}$ were analyzed by the chloroform-methanol extraction method of Kazuyoshi et al. (30). Lipids from strains F199 ${ }^{\mathrm{T}}$ and B0695 were subjected to the sequential saponification-hydrolysis procedure described by Mayberry and Lane (38). The resulting lipid extracts were spotted onto thin-layer chromatography plates $(250-\mu \mathrm{m}$-thick type $60 \mathrm{~A}$ plates obtained from Aldrich Chemical Co. Milwaukee, Wis.), which were subsequently developed with a two-step solvent system (chloroform to $15 \mathrm{~cm}$ and then hexane-diethyl ether [35:65, vol/vol]) Sphingoid bases were collected from the origin (between $R_{f}-0.1$ and $R_{f} 0.1$ ) and recovered by elution with chloroform-methanol $(2: 1, \mathrm{vol} / \mathrm{vol})$. The bases were derivatized in BSTFA (Pierce Chemical Co., Rockford, Ill.) to form trimethylsilyl ethers, which were then identified and quantified by GC-mass spectrometry as described above for the phospholipid fatty acids.

Nucleotide sequence accession numbers. The GenBank accession numbers for the 16S rDNA sequences determined in this study are as follows: F199 ${ }^{\mathrm{T}}$, U20756; B0477, U20772; B0478 ${ }^{\mathrm{T}}$, U20773; B0522, U20774; B0695, U20755; and B0712 ${ }^{\mathrm{T}}$, $\mathrm{U} 20775$.

\section{RESULTS}

Morphological and biochemical characteristics. All of the subsurface strains were non-spore-forming, nonmotile, gram- negative rods. The subsurface strains produced small (1- to 3-mm), yellow colonies on 5\% PTYG medium, although the $\mathrm{B} 0695$ and $\mathrm{B} 0712^{\mathrm{T}}$ colonies were noticeably lighter in color than the colonies of the other strains. Only strain B0712 produced a visible capsule when it was grown in $10 \%$ PTYG broth. The $\mathrm{G}+\mathrm{C}$ contents of the DNAs were as follows: $S$. capsulata ATCC 14666, $63.7 \mathrm{~mol} \%$; F199 ${ }^{\mathrm{T}}, 64.2 \mathrm{~mol} \%$; B0522, $62.9 \mathrm{~mol} \%$; B0695, 65.0 mol\%; B0478 ${ }^{\mathrm{T}}, 60.0 \mathrm{~mol} \%$; B0712 ${ }^{\mathrm{T}}$, $65.4 \mathrm{~mol} \%$; and $\mathrm{B} 0477,63.1 \mathrm{~mol} \%$. The predominant isoprenoid quinone in all strains was ubiquinone Q-10. These morphological and biochemical characteristics are consistent with the characteristics of members of the genus Sphingomonas (55, 64 ), except that the $\mathrm{G}+\mathrm{C}$ content of strain $\mathrm{B} 0478^{\mathrm{T}}$ is slightly lower than the range specified in the current genus description (61.6 to $67.8 \mathrm{~mol} \%$ ).

Phylogenetic analysis of 16S rRNA gene sequences. Phylogenetic trees depicting the results of distance matrix and parsimony analyses of $16 \mathrm{~S}$ rRNA gene sequences are shown in Fig. 1 and 2, respectively. Both analyses clearly indicated that the subsurface strains fall in the genus Sphingomonas, as it is currently defined $(55,64)$. Both analyses were also in agreement with respect to the phylogenetic relatedness of the subsurface strains to each other and to the various previously described Sphingomonas species that were included in the analysis.

Five of the subsurface strains $\left(\mathrm{B} 0478^{\mathrm{T}}, \mathrm{B} 0522, \mathrm{~B} 0695\right.$, $\mathrm{B} 0712^{\mathrm{T}}$, and $\mathrm{F} 199^{\mathrm{T}}$ ) formed a distinct cluster with $S$. capsulata (Fig. 1 and 2). Three of these strains (B0522, B0695, and F199 ${ }^{\mathrm{T}}$ ) were phylogenetically very closely related and had almost identical 16S rRNA gene sequences (the levels of similarity were 99.8 to $99.9 \%$ for 1,292 bases), implying that they may be members of the same species. The levels of sequence similarity between these strains and the two $S$. capsulata species included in the analysis were somewhat lower (97.8 to $98.0 \%$ ). Moreover, both analytical methods clearly separated the subsurface and $S$. capsulata strains on distinct branches of 


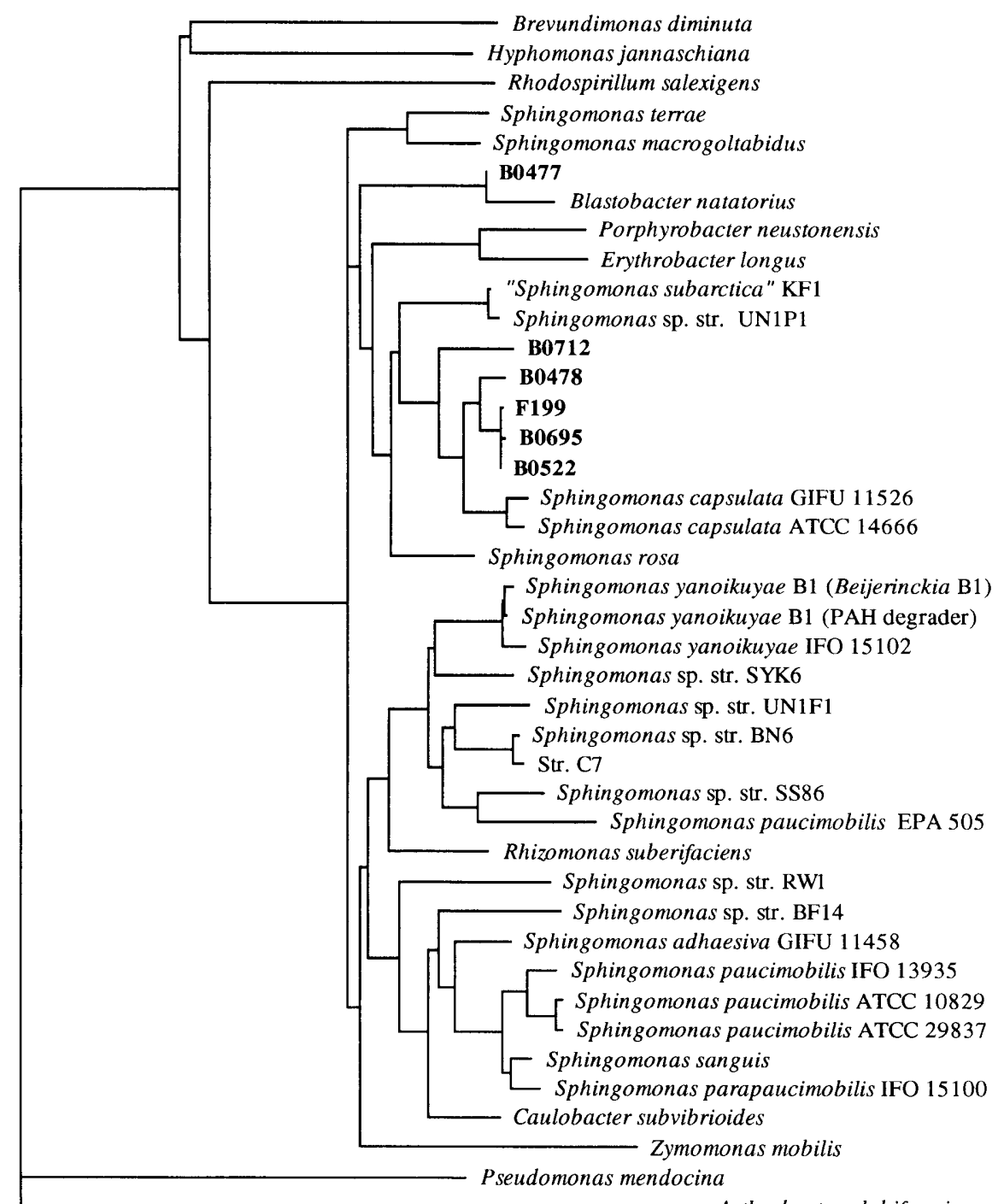

Arthrobacter globiformis

FIG. 1. Phylogenetic tree for six subsurface isolates and selected strains of eubacteria (see Table 1), based on a distance matrix analysis. The PHYLIP program (14) was used to calculate distances by the method of Jukes and Cantor (28), after which the FITCH option was used to estimate phylogenies from distance matrix data. Arthrobacter globiformis was used as the outgroup. Scale bar $=5$ substitutions per 100 bases.

the trees. These results imply that strains B0522, B0695, and F199 ${ }^{\mathrm{T}}$ are not strains of $S$. capsulata and may represent a separate species.

Subsurface strain $\mathrm{B} 0478^{\mathbf{T}}$ was phylogenetically most closely related to strains $\mathrm{B} 0522, \mathrm{~B} 0695$, and $\mathrm{F} 199^{\mathrm{T}}$, but was always separated from those strains on a distinct branch of the trees (Fig. 1 and 2). It was not clear from the levels of sequence similarity (98.9 to $99.0 \%$ ) whether $\mathrm{B} 0478^{\mathrm{T}}$ might differ from the other three subsurface strains at the species level. On the other hand, B0478 ${ }^{\mathrm{T}}$ was as phylogenetically distant from $S$. capsulata as the other three subsurface strains were, and the levels of sequence similarity between it and the $S$. capsulata strains $(97.8$ to $97.9 \%$ ) were in a range that some have suggested is too low for members of a single species $(7,11)$.

Both analytical methods clearly separated subsurface strain B0712 ${ }^{\mathrm{T}}$ from all of the strains described above (including $S$. capsulata) and assigned it to a distinct and comparatively deep branch of the tree (Fig. 1 and 2). This finding and the levels of sequence similarity between $\mathrm{B} 0712^{\mathrm{T}}$ and the strains described above ( 96.1 to $97.2 \%$ ) imply that $\mathrm{B} 0712^{\mathrm{T}}$ is a member of a distinct Sphingomonas species.

Subsurface strain B0477 did not cluster with $S$. capsulata and the other subsurface isolates (Fig. 1 and 2). Of the species for which sequences were available from the RDP or GenBank/ EMBL, B0477 was most closely related to Blastobacter natatorius (level of sequence similarity, $99.1 \%$ ).

The results of the sequence analyses were in general agreement with the results of previous studies $(41,55-57,64)$ with regard to the overall phylogenetic arrangement of the genus Sphingomonas. Some of the higher-order branching was not resolved consistently in the bootstrap parsimony analysis (Fig. 2 ). Nevertheless, the clustering of species and the relative distances were very much as reported previously. For example, the clustering and order of branching for Sphingomonas adhae- 


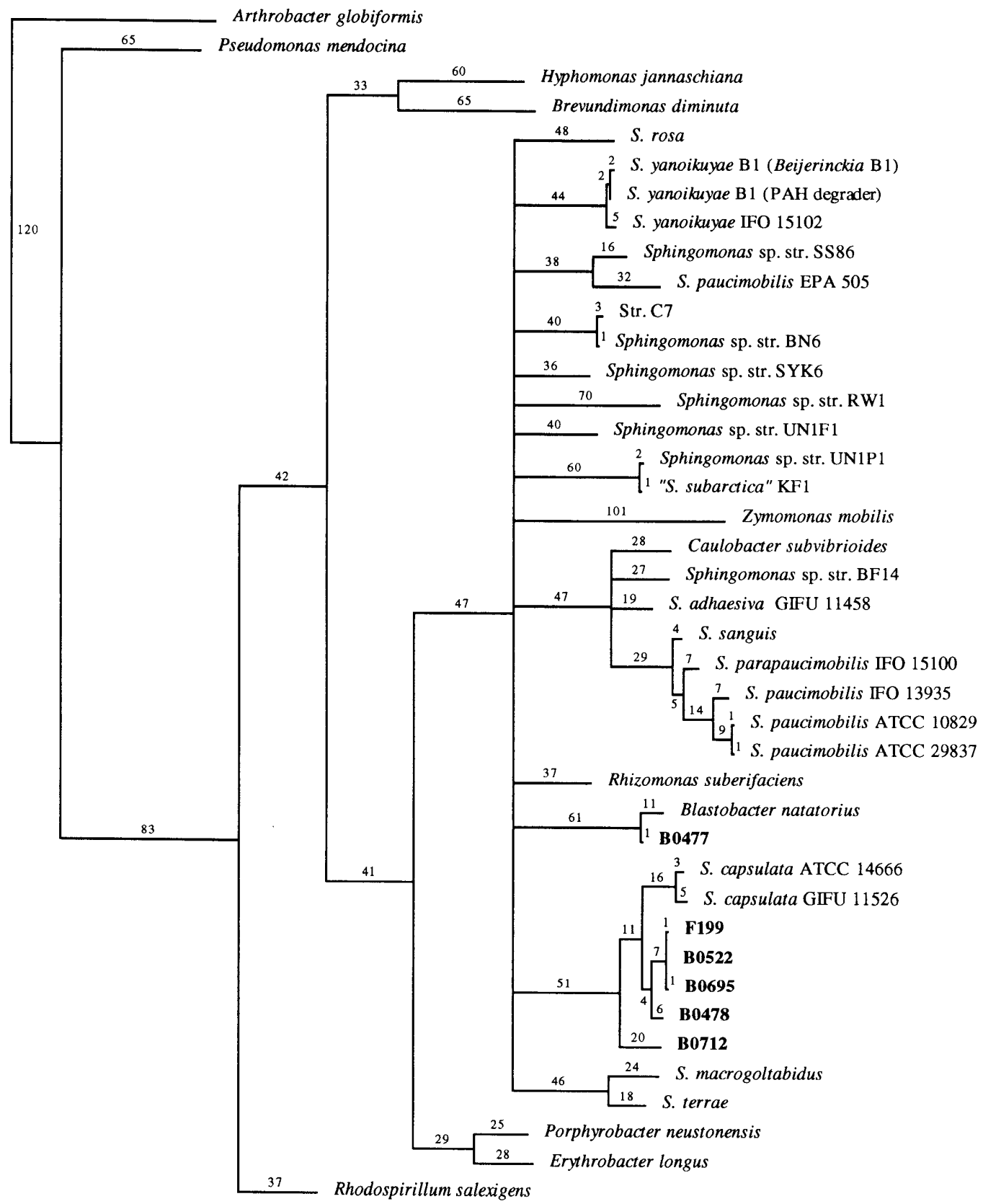

FIG. 2. Consensus phylogenetic tree for six subsurface isolates and selected strains of eubacteria (see Table 1), based on parsimony analysis. The PAUP program (53) was used to analyze 1,252 characters of aligned nucleotide sequences. A heuristic search retained two trees with a minimum length of 1,518 steps that differed only in the branching order of $S$. macrogoltabidus and S. terrae. The tree shown was generated by bootstrapping at the greater-than-50\% confidence limits, with 100 replications (13). The number above each branch is the branch length. Arthrobacter globiformis was used as the outgroup.

siva, Sphingomonas sanguis, S. paucimobilis, and Sphingomonas parapaucimobilis, as well as the clustering and order of branching for Sphingomonas macrogoltabidus and Sphingomonas terrae, were identical to the clustering and order of branching reported by Takeuchi et al. (56). Interestingly, the subsurface strains did not cluster with Sphingomonas isolates that have been reported to degrade dibenzo- $p$-dioxin (RW1), chlorophenol (KF1), or polyaromatic hydrocarbons (e.g., B1, UN1F1, and UN1P1).

DNA-DNA reassociation analysis. Stackebrandt and Goebel (49) recently recommended that DNA-DNA reassociation val- ues be used to assess whether strains are members of a single species when levels of 16S rRNA sequence similarity are $97 \%$ or higher. Therefore, a DNA-DNA reassociation analysis was carried out to obtain more definitive information on the various species level relationships among the subsurface strains and $S$. capsulata that were implied by the $16 \mathrm{~S}$ rRNA gene sequence analysis (see above). The results of this analysis (Table 2) indicated that subsurface strains B0522, B0695, and F199 ${ }^{\mathrm{T}}$ had DNA-DNA reassociation values between 60 and $116 \%$ (depending on which DNA was used as the probe). The Ad Hoc Committee on Reconciliation of Approaches to Bac- 
TABLE 2. DNA-DNA reassociation values for various Sphingomonas strains

\begin{tabular}{|c|c|c|c|c|c|c|c|c|c|c|}
\hline \multirow{2}{*}{ Isolate } & \multicolumn{10}{|c|}{$\%$ Reassociation with labeled DNA from: } \\
\hline & ATCC 51230 & ATCC 14666 & F199 ${ }^{\mathrm{T}}$ & B0522 & B0695 & $\mathrm{B} 0478^{\mathrm{T}}$ & $\mathrm{B} 0712^{\mathrm{T}}$ & B0477 & B1 & Q1 \\
\hline S. yanoikuyae ATCC 51230 & 100 & 4 & 0 & 2 & 1 & 2 & 2 & 1 & 53 & 32 \\
\hline S. capsulata ATCC 14666 & 10 & 100 & 3 & 4 & 6 & 6 & 4 & 2 & 11 & 8 \\
\hline Sphingomonas sp. strain F199 ${ }^{\mathrm{T}}$ & 13 & 5 & 100 & 73 & 60 & 14 & 7 & 3 & 10 & 6 \\
\hline Sphingomonas sp. strain B0522 & 5 & 6 & 107 & 100 & 66 & 17 & 8 & 1 & 5 & 4 \\
\hline Sphingomonas sp. strain B0695 & 8 & 8 & 116 & 98 & 100 & 21 & 10 & 2 & 6 & 9 \\
\hline Sphingomonas sp. strain B0478 & 5 & 9 & 16 & 16 & 11 & 100 & 8 & 7 & 3 & 4 \\
\hline Sphingomonas sp. strain $\mathrm{B} 0712^{\mathrm{T}}$ & 7 & 9 & 10 & 7 & 10 & 9 & 100 & 3 & 12 & 6 \\
\hline Sphingomonas sp. strain B0477 & 8 & 5 & 0 & 4 & 3 & 13 & 5 & 100 & 7 & 13 \\
\hline S. yanoikuyae B1 & 53 & 4 & 0 & 1 & 3 & 5 & 2 & 1 & 100 & 44 \\
\hline S. yanoikuyae Q1 & 31 & 5 & 1 & 1 & 2 & 3 & 0 & 1 & 33 & 100 \\
\hline
\end{tabular}

terial Systematics (61) has suggested that a phylogenetically defined species consists of strains that exhibit approximately $70 \%$ or greater DNA-DNA relatedness and a difference in the denaturation temperatures of homoduplexes and heteroduplexes of $5^{\circ} \mathrm{C}$ or less. Takeuchi et al. $(55,56)$ have used similar criteria in defining several new species of the genus Sphingomonas. Thus, the reassociation values strongly imply that strains B0522, B0695, and F199 ${ }^{\mathrm{T}}$ are members of a single species. The reassociation values between these strains and all other strains tested (Table 2) were less than $21 \%$, however, strongly implying that these three strains were distinct from the other strains at the species level.

The DNA-DNA reassociation values between subsurface strain $\mathrm{B} 0478^{\mathrm{T}}$ and all other strains were no higher than $21 \%$, while the DNA-DNA reassociation values between strain $\mathrm{B} 0712^{\mathrm{T}}$ and all other strains were no higher than $12 \%$. These results indicate that $\mathrm{B} 0478^{\mathrm{T}}$ and $\mathrm{B} 0712^{\mathrm{T}}$ are both highly likely to be members of distinct Sphingomonas species.

BOX-PCR genomic fingerprints. Genomic fingerprinting of bacteria based on PCR of repeated sequence regions can be used to determine the degrees of similarity of closely related bacteria and to determine whether similar strains are clonally related (59). The BOX-PCR method has been used successfully to identify and classify Xanthomonas and Pseudomonas strains (35) and was used in this study to characterize the genomic structure of the subsurface Sphingomonas strains. Subsurface Sphingomonas strains B0695 and B0522 share the greatest number of bands in the BOX fingerprints (Fig. 3) but are clearly not clonal. F199 $9^{\mathrm{T}}$ also shares several bands with B0695 and B0522, but all three of these isolates are quite distinct from the $S$. capsulata type strain. The remaining subsurface strains $\left(\mathrm{B} 0477, \mathrm{~B} 0478^{\mathrm{T}}\right.$, and $\mathrm{B} 0712^{\mathrm{T}}$ ) are clearly distinct from each other and from the type strains.

Physiological characteristics. Representative physiological characteristics of $S$. paucimobilis, $S$. capsulata, and the subsurface strains are summarized in Table 3 . The physiological traits of the subsurface strains generally matched those of the genus Sphingomonas, as defined by Yabuuchi et al. (64) and emended by Takeuchi et al. (55) (catalase positive; oxidative acid production from pentoses, hexoses, and disaccharides, but not from inulin or polyalcohols). The only exception was strain B0477, which failed to produce acid from glucose, maltose, and raffinose.

Subsurface strains B0522, B0695, and $\mathrm{F} 199^{\mathrm{T}}$ had virtually identical physiological traits, a finding that is consistent with the evidence (from 16S rRNA gene sequence, DNA-DNA reassociation, and $\mathrm{BOX}-\mathrm{PCR}$ analyses [see above]) that they are members of a single species. Their physiological traits differed from those of $S$. capsulata (the phylogenetically most closely related species of Sphingomonas) in several ways, most notably in the ability to grow readily on aromatic compounds such as benzoate, $p$-cresol, and $m$-xylene (Table 3) (16).

The physiological characteristics of subsurface strains $B 0478^{\mathrm{T}}$ and $\mathrm{B} 0712^{\mathrm{T}}$ were quite similar, except for the types of aromatic compounds on which they could grow (Table 3) (16). They differed from $S$. capsulata and $S$. paucimobilis in their ability to grow on aromatic compounds and their failure to aerobically assimilate L-malate or produce acid from galactose. Strains

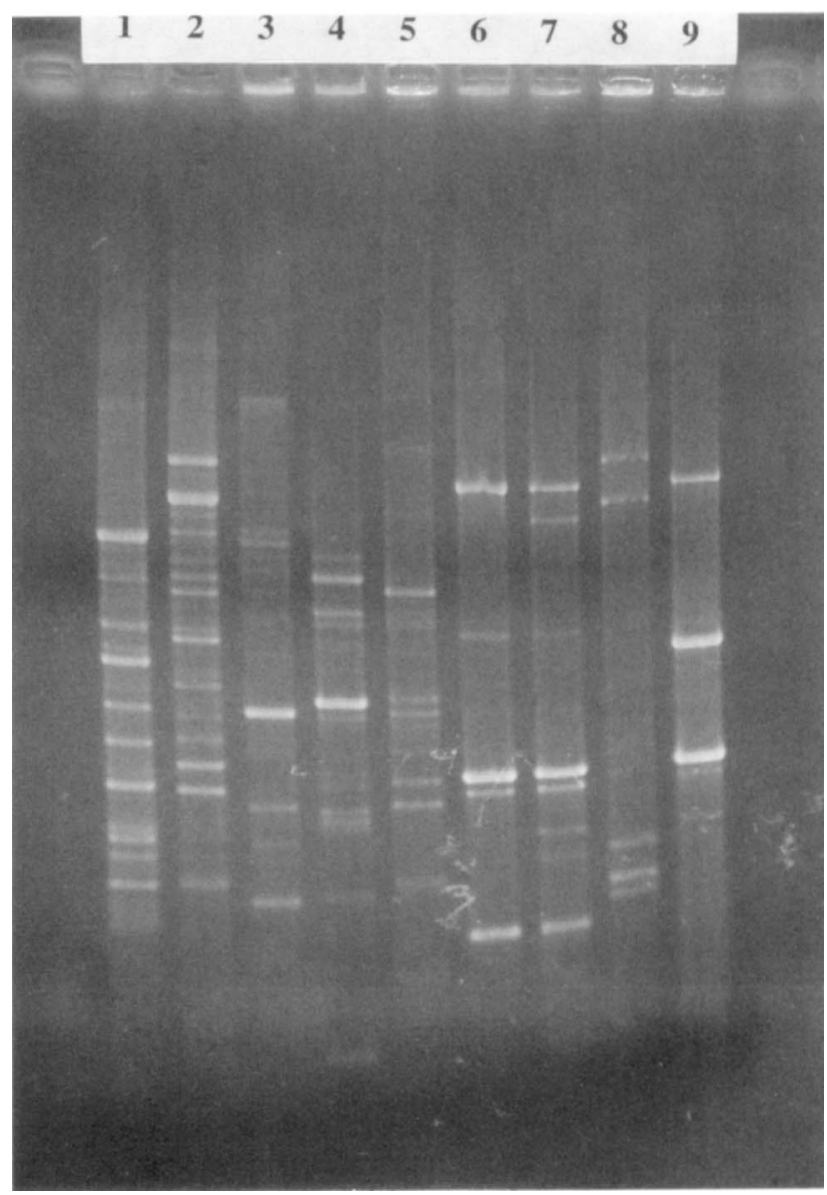

FIG. 3. BOX-PCR fingerprints of $\mathrm{F} 199^{\mathrm{T}}$ (lane 1), B0712 ${ }^{\mathrm{T}}$ (lane 2), B0695 (lane 3), B0522 (lane 4), B0478 (lane 5), B0477 (lane 6), S. paucimobilis ATCC 29837 (lane 7), S. capsulata ATCC 14666 (lane 8), and Burkholderia cepacia (lane 9). 
TABLE 3. Physiological characteristics of Sphingomonas strains ${ }^{a}$

\begin{tabular}{|c|c|c|c|c|c|c|c|}
\hline Physiological characteristic & $\begin{array}{l}\text { S. paucimobilis } \\
\text { ATCC } 29837\end{array}$ & $\begin{array}{l}\text { S. capsulata } \\
\text { ATCC } 14666\end{array}$ & $\begin{array}{l}\mathrm{F} 199^{\mathrm{T}}, \mathrm{B} 0522, \\
\text { and } \mathrm{B} 0695\end{array}$ & $\mathrm{~B} 0478^{\mathrm{T}}$ & $\mathrm{B} 0712^{\mathrm{T}}$ & B0477 & $\begin{array}{l}\text { Test basis or } \\
\text { reference }\end{array}$ \\
\hline$N$-Acetyl- $\beta$-glucosaminidase activity & + & - & + & - & - & - & $\mathrm{Z}$ \\
\hline \multicolumn{8}{|l|}{ Aerobic assimilation of: } \\
\hline L-Arabinose & + & + & - & $+1-$ & + & - & $\mathrm{N}$ \\
\hline Adipate & - & - & $+1-$ & - & - & - & $\mathrm{N}$ \\
\hline D-Gluconate & - & + & - & - & - & - & $\mathrm{N}$ \\
\hline L-Malate & + & + & - & - & - & - & $\mathrm{N}$ \\
\hline \multicolumn{8}{|l|}{$\begin{array}{l}\text { Relative growth on the following } \\
\text { aromatic compounds : }\end{array}$} \\
\hline Benzoate & - & - & + & + & + & + & 16 \\
\hline$p$-Cresol & - & + & ++ & - & - & - & 16 \\
\hline Naphthalene & - & - & + & + & - & - & 16 \\
\hline$m$-Xylene & - & - & ++ & - & $t+$ & - & 16 \\
\hline \multicolumn{8}{|l|}{ Oxidative acid production from: } \\
\hline L-Arabinose & - & + & - & + & + & - & $\mathrm{O}$ \\
\hline L-Fucose & - & + & - & - & - & - & $\mathrm{C}$ \\
\hline Galactose & + & + & - & - & - & - & C \\
\hline Glucose & + & + & + & + & + & - & $\mathrm{O}, \mathrm{C}$ \\
\hline Maltose & + & + & + & + & + & - & $\mathrm{C}$ \\
\hline Raffinose & + & + & + & + & $+1-$ & - & $\mathrm{O}, \mathrm{C}$ \\
\hline Sucrose & + & + & + & + & + & $+1-$ & $\mathrm{O}, \mathrm{C}$ \\
\hline Trehalose & - & + & - & - & - & - & $\mathrm{O}$ \\
\hline D-Xylose & + & + & + & + & - & - & C \\
\hline
\end{tabular}

${ }^{a}$ All strains were positive for catalase and esculin hydrolysis. All strains were negative for glucose fermentation; indole production; urease; gelatin hydrolysis; arginine dihydrolase; and oxidative acid production from D-arabinol, L-arabinol, dulcitol, inulin, mannitol, and sorbitol.

${ }^{b} \mathrm{C}$, API 50CH; O, Difco OF medium; N, API NFT; Z, API ZYM (see Materials and Methods).

${ }^{c}$ These plasmid-encoded traits are included for comparison only; they are not presented as defining taxonomic traits.

$\mathrm{B} 0478^{\mathrm{T}}$ and $\mathrm{B} 0712^{\mathrm{T}}$ differed from strains B0522, B0695, and $\mathrm{F} 199^{\mathrm{T}}$ in growth on certain aromatic compounds, aerobic assimilation of L-arabinose, and oxidative acid production from L-arabinose.

Chemical characteristics. Sphingolipids were present in all of the subsurface strains, although there were differences among the strains with respect to the relative amounts of specific lipids (16). The predominant long-chain bases in $\mathrm{F} 199^{\mathrm{T}}$ and B0695 were cy21:0 and 18:0, whereas cy20:0 and 18:0 were the predominant bases in strains $\mathrm{B} 0712^{\mathrm{T}}, \mathrm{B} 0522, \mathrm{~B} 0478^{\mathrm{T}}$, and B0477. The predominant sphinganine bases in the $S$. paucimobilis and $S$. capsulata type strains were 18:0 and cy21:0.

In all of the subsurface Sphingomonas strains and in the $S$. capsulata and $S$. paucimobilis type strains, the major hydroxy fatty acid was 2OH14:0 (Table 4). However, there were a number of differences in the relative amounts of minor hydroxy fatty acids among the various strains. For example, the subsurface strains generally had greater amounts of $2 \mathrm{OH} 15: 0$, 2OH16:0, and 2OH17:1 than the type strains, whereas the $S$. capsulata type strain had a greater amount of $2 \mathrm{OH} 14: 1$ than the other strains. Of all of the strains tested, B0477 was the most different in terms of its hydroxy fatty acid profile.

There were also several differences in the relative amounts of total lipid fatty acid components in the various strains tested (Table 5). For example, 18:1 $15 \mathrm{c}, 18: 0$, and br19:1 were present in F199 ${ }^{\mathrm{T}}, \mathrm{B} 0695$, and B0522, but were not detected in the $S$. capsulata type strain. Among the strains tested, B0477 had the most unusual total lipid fatty acid profile.

The lipid compositions of all of the subsurface strains fit the current description of the genus Sphingomonas (55) in that 18:1 was a major constituent of the cellular lipids, the predominant hydroxy fatty acids were 2OH14:0 and 2OH15:0, and long-chain sphinganine bases were present. In addition to differences in the lipid and fatty acid compositions of the cellular membranes among the various subsurface strains, there were several substantial differences between the subsurface strains and S. capsulata and S. paucimobilis. Strains F199 ${ }^{\mathrm{T}}$, B0695, and B0522 contained between 9.8 and 35.4 mol\% br19:1, whereas this fatty acid was not detected in the two type strains (Table 5). Strain $\mathrm{B} 0478^{\mathrm{T}}$ contained 4.3 mol\% br19:1, but $\mathrm{B} 0712^{\mathrm{T}}$ and B0477 did not contain detectable levels of this fatty acid. Also, the subsurface strains contained small amounts of several odd-numbered hydroxy fatty acids (including 2OH13:0 and 2OH17:1) that were not detected in the type strains (Table 4).

\section{DISCUSSION}

The morphological, physiological, and biochemical characteristics of subsurface strains B0478 ${ }^{\mathrm{T}}, \mathrm{B} 0522, \mathrm{~B} 0695, \mathrm{~B} 0712^{\mathrm{T}}$, and $\mathrm{F} 199^{\mathrm{T}}$ are consistent with the characteristics of the genus Sphingomonas, as defined by Yabuuchi et al. (64) and emended by Takeuchi et al. (55). The $\mathrm{G}+\mathrm{C}$ contents of strains B0522, $\mathrm{B} 0695, \mathrm{~B} 0712^{\mathrm{T}}$, and $\mathrm{F} 199^{\mathrm{T}}(62.9$ to $65.4 \mathrm{~mol} \%)$ were well

TABLE 4. Levels of hydroxy fatty acids in strain ATCC 14666 and subsurface Sphingomonas strains

\begin{tabular}{lrrrrrrr}
\hline & \multicolumn{7}{c}{ mol\% in: } \\
\cline { 2 - 8 } Fatty acid & $\begin{array}{c}\text { S. capsulata } \\
\text { ATCC } \\
\end{array}$ & F199 & B0552 & B0695 & B0478 & B0712 & B0477 \\
\hline 2OH12:0 & 0.8 & 2.1 & 0.9 & 2.0 & 0.8 & 1.0 & 0.1 \\
2OH13:0 & 0.0 & 1.8 & 1.8 & 0.7 & 2.3 & 2.4 & 0.1 \\
2OH14:1 & 3.6 & 0.5 & 0.6 & 0.0 & 0.2 & 0.7 & 0.0 \\
2OH14:0 & 86.1 & 84.6 & 77.4 & 93.1 & 75.8 & 79.8 & 34.4 \\
2OH15:0 & 1.8 & 5.9 & 8.8 & 2.5 & 13.3 & 3.5 & 11.5 \\
18:1/2OH16:1 & 1.5 & 0.4 & 3.0 & 0.2 & 1.2 & 5.4 & 2.6 \\
18:0/2OH16:1 & 5.7 & 2.1 & 4.7 & 0.3 & 3.6 & 6.3 & 26.4 \\
2OH16:0 & 0.5 & 1.4 & 1.3 & 0.9 & 2.2 & 0.6 & 24.2 \\
2OH17:1 & 0.0 & 0.5 & 0.7 & 0.3 & 0.5 & 0.2 & 0.5 \\
2OH18:1 & 0.0 & 0.7 & 0.9 & 0.0 & 0.1 & 0.1 & 0.2 \\
\hline & & & & & & &
\end{tabular}


TABLE 5. Levels of total lipid fatty acids in strain ATCC 14666 and subsurface Sphingomonas strains

\begin{tabular}{|c|c|c|c|c|c|c|c|}
\hline \multirow[b]{2}{*}{$\begin{array}{l}\text { Polar lipid } \\
\text { fatty acid }\end{array}$} & \multicolumn{7}{|c|}{ mol\% in: } \\
\hline & $\begin{array}{c}\text { S. capsulata } \\
\text { ATCC } \\
14666\end{array}$ & $\mathrm{~F} 199^{\mathrm{T}}$ & B0522 & B0695 & $\mathrm{B} 0478^{\mathrm{T}}$ & $\mathrm{B} 0712^{\mathrm{T}}$ & B0477 \\
\hline 2OH12:0 & 2.0 & 0.0 & 1.6 & 0.0 & 0.4 & 0.8 & 0.1 \\
\hline $14: 0$ & 0.7 & 1.1 & 0.3 & 0.1 & 0.7 & 2.5 & 0.0 \\
\hline Unknown 1 & 9.0 & 0.6 & 2.3 & 0.2 & 1.0 & 1.2 & 0.5 \\
\hline 2OH14:0 & 47.8 & 26.7 & 39.5 & 24.5 & 36.7 & 38.8 & 177 \\
\hline $16: 1 \omega 7 \mathrm{c}$ & 0.9 & 2.8 & 2.1 & 2.2 & 2.3 & 3.1 & 2.2 \\
\hline $16: 1 \omega 5 \mathrm{c}$ & 0.0 & 0.3 & 0.2 & 0.1 & 0.2 & 1.3 & 0.8 \\
\hline $16: 0$ & 1.7 & 3.3 & 1.3 & 6.4 & 2.3 & 2.3 & 5.7 \\
\hline 2OH15:0 & 0.0 & 2.2 & 3.9 & 1.2 & 5.0 & 3.0 & 2.1 \\
\hline $17: 1 \omega 6 \mathrm{c}$ & 0.7 & 1.1 & 1.0 & 0.5 & 2.2 & 1.6 & 3.0 \\
\hline 2OH16:1 & 1.0 & 2.0 & 2.7 & 0.6 & 1.3 & 1.8 & 0.5 \\
\hline 17:0/2OH $16: 1$ & 3.9 & 1.3 & 3.9 & 1.0 & 3.2 & 7.8 & 20.0 \\
\hline 2OH16:0 & 0.0 & 1.1 & 0.8 & 1.0 & 1.6 & 1.0 & 2.5 \\
\hline $18: 1 \omega 7 \mathrm{c}$ & 32.5 & 38.0 & 28.4 & 20.9 & 35.8 & 31.3 & 42.3 \\
\hline $18: 1 \omega 5 \mathrm{c}$ & 0.0 & 1.5 & 0.6 & 1.2 & 1.5 & 3.0 & 1.9 \\
\hline $18: 0$ & 0.0 & 0.6 & 1.2 & 1.4 & 1.4 & 0.5 & 0.9 \\
\hline br19:1 & 0.0 & 16.6 & 9.8 & 35.4 & 4.3 & 0.0 & 0.0 \\
\hline cy19:0 & 0.0 & 0.8 & 0.5 & 3.3 & 0.0 & 0.0 & 0.0 \\
\hline
\end{tabular}

within the range of values reported for established Sphingomonas species $(61.7$ to $67.8 \mathrm{~mol} \%)(56)$. The only exception was strain $\mathrm{B} 0478^{\mathrm{T}}(\mathrm{G}+\mathrm{C}$ content, $60.0 \mathrm{~mol} \%)$, but in phylogenetic analyses of $16 \mathrm{~S}$ rRNA sequences (Fig. 1 and 2), this isolate consistently clustered with $S$. capsulata and the other subsurface strains (except B0477). Moreover, strain B0478 ${ }^{\mathrm{T}}$ (like the other subsurface strains) contained ubiquinone Q-10 as the predominant isoprenoid quinone. Based on these findings, we conclude that subsurface strains $\mathrm{B} 0478^{\mathrm{T}}$, B0522, B0695, $\mathrm{B} 0712^{\mathrm{T}}$, and $\mathrm{F} 199^{\mathrm{T}}$ are members of the genus Sphingomonas, as it is currently defined. The taxonomic status of strain B0477 is not clear because some of its physiological traits are not consistent with the physiological traits of the genus Sphingomonas and phylogenetic analyses indicated that it was most closely related to $B$. natotorius. Additional studies will be needed to fully classify this isolate.

On the basis of physiological characteristics, the results of DNA-DNA reassociation studies, and $16 \mathrm{~S}$ rRNA gene sequence analysis, we propose the following three new species of the genus Sphingomonas: Sphingomonas aromaticivorans (for strains B0522, B0695, and F199 ${ }^{\mathrm{T}}$ [SMCC F199 $\left.{ }^{\mathrm{T}}\right]$ ), Sphingomonas subterranea (type strain, B0478 [SMCC B0478]), and Sphingomonas stygia (type strain, B0712).

The analysis of $16 \mathrm{~S}$ rRNA gene sequences placed the proposed new Sphingomonas species in a well-defined cluster with $S$. capsulata. In 1993, van Bruggen et al. (58) suggested that $S$. capsulata should be transferred to a new genus and that $S$. yanoikuyae should be placed in the genus Rhizomonas. Based on the results of a phylogenetic analysis of 16S rRNA gene sequences, Takeuchi et al. (57) agreed with these suggestions. More recently, Takeuchi et al. (56) suggested that the genus Sphingomonas sensu stricto should be restricted to the species $S$. paucimobilis, S. parapaucimobilis, $S$. sanguis, and $S$. adhaesiva and that all other species should eventually be transferred to other genera. A revision of the genus Sphingomonas was beyond the scope of this study, but if $S$. capsulata is moved to a separate genus, as has been suggested, the results of our 16S rRNA gene sequence analyses indicate that the proposed new subsurface species may also be members of that genus.
The new Sphingomonas species are described below.

Description of Sphingomonas aromaticivorans sp. nov. Sphingomonas aromaticivorans (a.ro.ma.ti.ci'vo.rans. N. L. n. aromaticus, aromatic compound; L. part. vorans, eating; aromaticivorans, eating aromatic compounds) is a gram-negative, nonsporing, nonmotile, rod-shaped organism. Colonies are circular, entire, low convex, smooth, opaque, and yellow. Indole, urease, and arginine dihydrolase are not produced. Catalase positive. Gelatin is not liquefied, and glucose is not fermented. Adipate and esculin are assimilated aerobically, but L-arabinose, D-gluconate, and L-malate are not assimilated aerobically. Acid is produced oxidatively from glucose, maltose, raffinose, sucrose, and D-xylose, but not from L-arabinose, D- or L-arabitol, dulcitol, L-fucose, inulin, mannitol, sorbitol, or trehalose.

The $\mathrm{G}+\mathrm{C}$ content of the DNA is 62.9 to $65.0 \mathrm{~mol} \%$. The major isoprenoid quinone is ubiquinone Q-10. The major non-

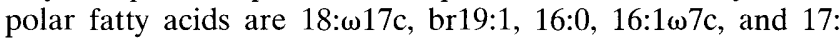
$1 \omega 6 \mathrm{c}$, and the major 2-hydroxy fatty acids are 2OH14:0 and 2OH15:0. Sphingolipid is present. Source: isolated from saturated Atlantic coastal plain terrestrial subsurface sediments.

The type strain is F199 (= SMCC F199), and reference strains include strains B0522 (= SMCC B0522) and B0695 (= SMCC B0695).

Description of Sphingomonas subterranea sp. nov. Sphingomonas subterranea (sub.ter.ra'ne.a. L. adj. subterraneus, - $a$, underground, subterranean) is a gram-negative, nonsporing, nonmotile, rod-shaped organism. Colonies are circular, entire, low convex, dry, smooth, opaque, and yellow. Indole, urease, and arginine dihydrolase are not produced. Catalase positive. Gelatin is not liquefied, and glucose is not fermented. Esculin is assimilated aerobically, but adipate, D-gluconate, and Lmalate are not assimilated aerobically. Acid is produced oxidatively from L-arabinose, glucose, maltose, raffinose, sucrose, and D-xylose, but not from D- or L-arabitol, dulcitol, L-fucose, galactose, inulin, mannitol, sorbitol, or trehalose.

The $\mathrm{G}+\mathrm{C}$ content of the DNA is $60.0 \mathrm{~mol} \%$. The major isoprenoid quinone is ubiquinone Q-10. The major nonpolar

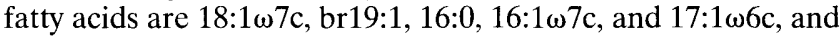
the major 2-hydroxy fatty acids are 2OH14:0 and 2OH15:0. Sphingolipid is present. Source: isolated from saturated Atlantic coastal plain terrestrial subsurface sediments.

The type strain is B0478 (= SMCC B0478).

Description of Sphinogomonas stygia sp. nov. Sphingomonas stygia (sty'gi.a. L. masc. n. Styx, underworld river in classical Greek mythology. L. adj. stygius, - $a$, pertaining to the underworld, subterranean) is a gram-negative, nonsporing, nonmotile, rod-shaped organism. Colonies are circular, entire, low convex, smooth, opaque, and yellow. Indole, urease, and arginine dihydrolase are not produced. Catalase positive. Gelatin is not liquified, and glucose is not fermented. Esculin and L-arabinose are assimilated aerobically, but adipate, D-gluconate, and L-malate are not assimilated aerobically. Acid is produced oxidatively from L-arabinose, glucose, maltose, and sucrose, but not from D- or L-arabitol, dulcitol, L-fucose, galactose, inulin, mannitol, sorbitol, trehalose, or D-xylose.

The $\mathrm{G}+\mathrm{C}$ content of the DNA is $65.4 \mathrm{~mol} \%$. The major isoprenoid quinone is ubiquinone Q-10. The major nonpolar fatty acids are $18: 1 \omega 7 \mathrm{c}, 16: 1 \omega 7 \mathrm{c}, 18: 1 \omega 5 \mathrm{c}, 14: 0$, and 16:0, and the major 2-hydroxy fatty acids are 2OH14:0, 18:0/2OH16:1, 18:1/2OH16:1, and 2OH15:0. Sphingolipid is present. Source: isolated from saturated Atlantic coastal plain terrestrial subsurface sediments.

The type strain is B0712 (= SMCC B0712). 


\section{ACKNOWLEDGMENTS}

We thank David R. Boone (Oregon Graduate Institute of Science and Technology, Portland) for advice concerning the orthography of the specific epithets. We thank Gerben J. Zylstra (Center for Agricultural Molecular Biology, Rutgers University, New Brunswick, N.J.) for providing cultures of $S$. yanoikuyae B1 and Q1. The continued support of F. J. Wobber is greatly appreciated.

This research was supported by the Deep Microbiology Subprogram of the Subsurface Science Program, Office of Health and Environmental Research, DOE. Pacific Northwest National Laboratory is operated for the DOE by Battelle Memorial Institute under contract DE-AC0676RLO 1830. Support for morphological characterization was provided in part by a grant from the DOE Laboratory Technology Research Division under the terms of a cooperative research and development agreement. The research and the SMCC at Florida State University were supported by DOE grants DE-FG05-91ER-61159 and DE-FG05-90ER61039, respectively. The research at the University of Tennessee was supported by DOE grant DE-FG05-90ER60988.

\section{REFERENCES}

1. Applied Biosystems, Inc. 1992. Taq DyeDeoxy terminator cycle sequencing kit user builetin no. 901497, revision E. Applied Biosystems, Inc., Foster City, Calif.

2. Balkwill, D. L. 1989. Numbers, diversity, and morphological characteristics of aerobic, chemoheterotrophic bacteria in deep subsurface sediments from a site in South Carolina. Geomicrobiol. J. 7:33-51.

3. Balkwill, D. L. 1993. DOE makes subsurface cultures available. ASM News 59:504-506.

4. Balkwill, D. L., J. K. Fredrickson, and J. M. Thomas. 1989. Vertical and horizontal variations in the physiological diversity of the aerobic chemoheterotrophic bacterial microflora in deep Southeast Coastal Plain subsurface sediments. Appl. Environ. Microbiol. 55:1058-1065.

5. Balkwill, D. L., and W. C. Ghiorse. 1985. Characterization of subsurface bacteria associated with two shallow aquifers in Oklahoma. Appl. Environ. Microbiol. 50:580-588.

6. Bligh, E. C., and W. J. Dyer. 1959. A rapid method of total lipid extraction and purification. Can. J. Biochem. Physiol. 37:910-917.

7. Boone, D. R., Y. Liu, Z.-J. Zhao, D. L. Balkwill, G. R. Drake, T. O. Stevens, and H. C. Aldrich. 1995. Bacillus infernus sp. nov., an Fe(III)- and Mn(IV)reducing anaerobe from the deep terrestrial subsurface. Int. J. Syst. Bacteriol. 45:441-448.

8. Brosius, J., M. L. Palmer, P. J. Kennedy, and H. R. Noller. 1979. Complete nucleotide sequence of a $16 \mathrm{~S}$ ribosomal gene from Escherichia coli. Proc. Natl. Acad. Sci. USA 75:4801-4805.

9. Chapelle, F. H. 1993. Ground-water microbiology and geochemistry. John Wiley \& Sons, Inc., New York, N.Y.

10. Denhardt, D. T. 1966. A membrane-filter technique for the detection of complementary DNA. Biochem. Biophys. Res. Commun. 23:641-646.

11. Devereux, R., S. H. He, S. Orkland, D. A. Stahl, J. LeGall, and W. B. Whitman. 1990. Diversity and origin of Desulfovibrio species: phylogenetic definition of a family. J. Bacteriol. 172:3609-3613.

12. Doetsch, R. N. 1981. Determinative methods in light microscopy, p. 21-33. In P. Gerhardt, R. G. E. Murray, R. N. Costilow, E. W. Nester, W. A. Wood, N. R. Krieg, and G. B. Phillips (ed.), Manual of methods for general bacteriology. American Society for Microbiology, Washington, D.C.

13. Felsenstein, J. 1985. Confidence limits on phylogenies: an approach using the bootstrap. Evolution 39:783-791.

14. Felsenstein, J. 1993. PHYLIP (phylogeny inference package) version 3.5c. J. Felsenstein, University of Washington, Seattle.

15. Fitch, W. M., and E. Margoliash. 1967. Construction of phylogenetic trees. Science 155:279-284.

16. Fredrickson, J. K., D. L. Balkwill, G. R. Drake, M. F. Romine, D. B. Ringelberg, and D. C. White. 1995. Aromatic-degrading Sphingomonas from the deep subsurface. Appl. Environ. Microbiol. 61:1917-1922.

17. Fredrickson, J. K., D. L. Balkwill, J. M. Zachara, S. W. Li, F. J. Brockman, and M. A. Simmons. 1991. Physiological diversity and distributions of heterotrophic bacteria in deep Cretaceous sediments of the Atlantic Coastal Plain. Appl. Environ. Microbiol. 57:402-411.

18. Fredrickson, J. K., F. J. Brockman, D. J. Workman, S. W. Li, and T. O. Stevens. 1991. Isolation and characterization of a subsurface bacterium capable of growth on toluene, naphthalene, and other aromatic compounds. Appl. Environ. Microbiol. 57:796-803.

19. Fredrickson, J. K., T. R. Garland, R. J. Hicks, J. M. Thomas, S. W. Li, and K. M. McFadden. 1989. Autotrophic and heterotrophic bacteria in deep subsurface sediments and their relationship to sediment properties. Geomicrobiol. J. 7:53-56.

20. Fuerst, J. A., J. A. Hawkins, A. J. Holmes, L. T. Sly, C. J. Moore, and E. Stackebrandt. 1993. Porphyrobacter neustonensis gen. nov., sp. nov., an aerobic bacteriochlorophyll-synthesizing budding bacterium from freshwater. Int. J. Syst. Bacteriol. 43:125-134.
21. Govindaswami, M., T. M. Schmidt, D. C. White, and J. C. Loper. 1993. Phylogenetic analysis of a bacterial aerobic degrader of azo dyes. J. Bacteriol. 175:6062-6066.

22. Guckert, J. B., D. B. Ringelberg, D. C. White, R. S. Hanson, and B. J. Bratina. 1991. Membrane fatty acids as phenotypic markers in the polyphasic taxonomy of methylotrophs within the proteobacteria. J. Gen. Microbiol. 137:2631-2641.

23. Haldeman, D. L., P. S. Amy, D. Ringelberg, and D. C. White. 1993. Characterization of the microbiology within a $21 \mathrm{~m}^{3}$ section of rock from the deep subsurface. Microb. Ecol. 26:145-159.

24. Hugenholtz, P., E. Stackebrandt, and J. A. Fuerst. 1994. A phylogenetic analysis of the genus Blastobacter with a view to its future reclassification. Syst. Appl. Microbiol. 17:51-57.

25. Imai, R., Y. Nagata, M. Fukada, M. Takagi, and K. Yano. 1991. Molecular cloning of a Pseudomonas paucimobilis gene encoding for a 17-kilodalton polypeptide that eliminates $\mathrm{HCl}$ molecules from $\gamma$-hexachlorocyclohexane. J. Bacteriol. 173:6811-6819.

26. Johnson, J. L. 1981. Genetic characterization, p. 450-472. In P. Gerhardt, R. G. E. Murray, R. N. Costilow, E. W. Nester, W. A. Wood, N. R. Krieg, and G. B. Phillips (ed.), Manual of methods for general bacteriology. American Society for Microbiology, Washington, D.C.

27. Johnson, J. L. 1991. DNA reassociation experiments, p. 21-44. In E. Stackebrandt and M. Goodfellow (ed.), Nucleic acid techniques in bacterial systematics. John Wiley and Sons Ltd., London, United Kingdom.

28. Jukes, T. H., and C. R. Cantor. 1969. Evolution of protein molecules, p 21-132. In H. N. Munro (ed.), Mammalian protein metabolism. Academic Press, New York, N.Y.

29. Karlson, U., F. Rojo, J. D. van Elsas, and E. R. B. Moore. 1996. Genetic and serological evidence for the recognition of 4 pentachlorophenol-degrading bacterial strains as a species of the genus Sphingomonas. Appl. Syst. Microbiol. 18:539-548.

30. Kazuyoshi, K., U. Seydel, M. Matsuura, H. Danbara, E. T. Rietschel, and U. Zahringer. 1991. Chemical structure of glycosphingolipids isolated from Sphingomonas paucimobilis. Fed. Eur. Biochem. Soc. Lett. 292:107-110.

31. Khan, A. A., R.-F. Wang, W.-W. Cao, W. Franklin, and C. E. Cerniglia. 1996 Reclassification of a polycyclic aromatic hydrocarbon-metabolizing bacterium, Beijerinckia sp. strain B1, as Sphingomonas yanoikuyae by fatty acid analysis, protein pattern analysis, DNA-DNA hybridization, and $16 \mathrm{~S}$ ribosomal DNA sequencing. Int. J. Syst. Bacteriol. 46:466-469.

32. Kim, E., P. J. Aversano, M. F. Romine, R. P. Schneider, and G. J. Zylstra. 1996. Homology between genes for aromatic hydrocarbon degradation in surface and deep-subsurface Sphingomonas strains. Appl. Environ. Microbiol. 62:1467-1470.

33. Kuhm, A. E., A. Stolz, K.-L. Ngai, and H.-J. Knackmuss. 1991. Purification and characterization of a 1,2-dihydroxynaphthalene dioxygenase from a bacterium that degrades naphthalenesulfonic acids. J. Bacteriol. 173:3795-3802.

34. Lane, D. J., G. Pace, G. E. Olsen, D. A. Stahl, M. L. Sogin, and N. R. Pace. 1985. Rapid determination of 16S ribosomal RNA sequences for phylogenetic analyses. Proc. Natl. Acad. Sci. USA 82:6955-6959.

35. Louws, F. J., D. W. Fulbright, C. T. Stephens, and F. J. de Bruijn. 1994 Specific genomic fingerprints of phytopathogenic Xanthomonas and Pseudomonas pathovars and strains generated with repetitive sequences and PCR. Appl. Environ. Microbiol. 60:2286-2295.

36. Maidak, B. L., N. Larsen, M. J. McCaughey, R. Overbeek, G. J. Olsen, K. Fogel, J. Blandy, and C. R. Woese. 1994. The Ribosomal Database Project. Nucleic Acids Res. 22:3485-3487.

37. Martin, B., O. Humbert, M. Camara, E. Guenzi, J. Walker, T. Mitchell, P. Andrew, M. Prudhomme, G. Alloing, R. Hakenback, D. A. Morrison, G. J Boulnois, and J. Claverys. 1992. A highly conserved repetitive element located in the chromosome of Streptococcus pneumoniae. Nucleic Acids Res. 20:3479-3483

38. Mayberry, W. R., and J. R. Lane. 1993. Sequential saponification/acid hydrolysis/esterification in a one-tube method with enhanced recovery of both cyclopropane and hydroxylated fatty acids. J. Microbiol. Methods 18:21-32.

39. McBride, L. J., S. M. Koepf, R. A. Gibbs, W. Salser, P. E. Mayrand, M. W. Hunkapiller, and M. N. Kronick. 1989. Automated DNA sequencing methods involving polymerase chain reaction. Clin. Chem. 35:2196-2201.

40. Mesbah, M., and W. B. Whitman. 1989. Measurement of deoxyguanosine/ thymidine ratios in complex mixtures by high-performance liquid chromatography for determination of the mole percentage guanine + cytosine of DNA. J. Chromatogr. 479:297-306.

41. Moore, E. R. B., R.-M. Wittich, P. Fortnagel, and K. N. Timmis. 1993. 16 S ribosomal RNA gene sequence characterization and phylogenetic analysis of a dibenzo-p-dioxin-degrading isolate within the new genus Sphingomonas. Lett. Appl. Microbiol. 17:115-118.

42. Mueller, J. G., P. J. Chapman, B. O. Blattman, and P. H. Pritchard. 1990 Isolation of a fluoranthene-utilizing strain of Pseudomonas paucimobilis. Appl. Environ. Microbiol. 56:1079-1086.

43. Murphy, E. M., J. A. Schramke, J. K. Fredrickson, H. W. Bledsoe, A. J. Francis, D. S. Sklarew, and J. C. Linehan. 1992. The influence of microbial activity and sedimentary organic carbon on the isotope geochemistry of the Middendorf Aquifer. Water Resour. Res. 28:723-740. 
44. Nichols, P. D., J. K. Volkman, and R. B. Johns. 1983. Sterols and fatty acids of the marine unicellular alga, FCRG51. Phytochemistry 22:1447-1452.

44a.Nohynek, L. J., E.-L. Nurmiaho-Lassila, E. I. Suhonen, H.-J. Busse, M. Mohammadi, J. Hantula, F. Rainey, and M. S. Salkinoja-Salonen. 1996. Description of chlorophenol-degrading Pseudomonas sp. strains $\mathrm{KF}^{\mathrm{T}}$, KF3, and NKF1 as a new species of the genus Sphingomonas, Sphingomonas subarctica sp. nov. Int. J. Syst. Bacteriol. 46:1042-1055.

45. Pedersen, K., and S. Ekendahl. 1990. Distribution and activity of bacteria in deep granitic groundwaters of southeastern Sweden. Microb. Ecol. 20:37-52

46. Reeves, R. H., J. Y. Reeves, and D. L. Balkwill. 1995. Strategies for phylogenetic characterization of subsurface bacteria. J. Microbiol. Methods 21: 235-251.

47. Sambrook, J., E. F. Fritsch, and T. Maniatis. 1989. Molecular cloning: a laboratory manual, 2nd ed. Cold Spring Harbor Laboratory, Cold Spring Harbor, N.Y.

48. Schmidt, S., R.-M. Wittich, D. Erdmann, H. Wilkes, W. Francke, and P. Fortnagel. 1992. Biodegradation of diphenyl ether and its monohalogenated derivatives by Sphingomonas sp. strain SS3. Appl. Environ. Microbiol. 58: $2744-2750$

49. Stackebrandt, E., and B. M. Goebel. 1994. Taxonomic note: a place for DNA-DNA reassociation and $16 \mathrm{~S}$ rRNA sequence analysis in the present species definition in bacteriology. Int. J. Syst. Bacteriol. 44:846-849.

50. Stahl, D. A., R. Key, B. Flesher, and J. Smit. 1992. The phylogeny of marine and freshwater caulobacters. J. Bacteriol. 174:2193-2198.

51. Stevens, T. O., J. P. McKinley, and J. K. Fredrickson. 1993. Bacteria associated with deep, alkaline, anaerobic groundwaters in southeast Washington. Microb. Ecol. 25:35-50.

52. Stillwell, L. C., S. J. Thurston, R. P. Schneider, M. F. Romine, J. K Fredrickson, and J. D. Saffer. 1995. Physical mapping and characterization of a catabolic plasmid from the deep-subsurface bacterium Sphingomonas sp. strain F199. J. Bacteriol. 177:4537-4539.

53. Swofford, D. L. 1993. PAUP: phylogenetic analysis using parsimony, 3.0rd ed Illinois Natural History Survey, Champaign.

54. Taira, K., N. Hayase, N. Arimura, S. Yamashita, T. Miyazaki, and K. Furukawa. 1988. Cloning and nucleotide sequence of the 2,3-dihydroxybiphenyl dioxygenase gene from the PCB-degrading strain of Pseudomonas paucimobilis Q1. Biochemistry 27:3990-3996.

55. Takeuchi, M., F. Kawai, Y. Shimada, and A. Yokota. 1993. Taxonomic study of polyethylene glycol-utilizing bacteria: emended description of the genus Sphingomonas and new descriptions of Sphingomonas macrogoltabidus sp. nov., Sphingomonas sanguis sp. nov. and Sphingomonas terrae sp. nov. Syst. Appl. Microbiol. 16:227-238.
56. Takeuchi, M., T. Sakane, M. Yanagi, K. Yamasato, K. Hamana, and A Yokota. 1995. Taxonomic study of bacteria isolated from plants: proposal of Sphingomonas rosa sp. nov., Sphingomonas pruni sp. nov., Sphingomonas asaccharolytica sp. nov., and Sphingomonas mali sp. nov. Int. J. Syst. Bacteriol. 45:334-341.

57. Takeuchi, M., H. Sawada, H. Oyaizu, and A. Yokota. 1994. Phylogenetic evidence for Sphingomonas and Rhizomonas as nonphotosynthetic members of the alpha-4 subclass of the Proteobacteria. Int. J. Syst. Bacteriol. 44:308314.

58. van Bruggen, A. H. C., K. N. Jochimsen, E. M. Steinberger, P. Segers, and M. Gillis. 1993. Classification of Rhizomonas suberifaciens, unnamed Rhizomonas species, and Sphingomonas spp. in rRNA superfamily IV. Int. J. Syst. Bacteriol. 43:1-7.

59. Versalovic, J., M. Schneider, F. J. de Bruijn, and J. R. Lupski. 1994. Genomic fingerprinting of bacteria using repetitive sequence-based polymerase chain reaction. Methods Mol. Cell. Biol. 5:23-40.

60. Wang, Y., and P. C. K. Lau. 1996. Sequence and expression of an isocitrate dehydrogenase-encoding gene from a polycyclic aromatic hydrocarbon oxidizer, Sphingomonas yanoikuyae B1. Gene 168:15-21.

61. Wayne, L. G., D. J. Brenner, R. R. Colwell, P. A. D. Grimont, O. Kandler, M. L. Krichevsky, L. H. Moore, W. E. C. Moore, R. G. E. Murray, E. Stackebrandt, M. P. Starr, and H. G. Trüper. 1987. Report of the Ad Hoc Committee on Reconciliation of Approaches to Bacterial Systematics. Int. J. Syst. Bacteriol. 37:463-464.

62. Weisberg, W. G., S. M. Barns, D. A. Pelletier, and D. J. Lane. 1991. 16S ribosomal DNA amplification for phylogenetic study. J. Bacteriol. 173:697703.

63. Wittich, R.-M., H. Wilkes, V. Sinnwell, W. Francke, and P. Fortnagel. 1992 Metabolism of dibenzo-p-dioxin by Sphingomonas sp. strain RW1. Appl. Environ. Microbiol. 58:1005-1010.

64. Yabuuchi, E., I. Yano, H. Oyaizu, Y. Hashimoto, T. Ezaki, and H. Yamamoto. 1990. Proposals of Sphingomonas paucimobilis gen. nov. and comb. nov., Sphingomonas parapaucimobilis sp. nov., Sphingomonas yanoikuyae $\mathrm{sp}$ nov., Sphingomonas adhaesiva sp. nov., Sphingomonas capsulata comb. nov., and two genospecies of the genus Sphingomonas. Microbiol. Immunol. 34: 99-119.

65. Yurkov, V., E. Stackebrandt, A. Holmes, J. A. Fuerst, P. Hugenholtz, J. Golecki, N. Gad'on, V. M. Gorlenko, E. I. Kompantseva, and G. Drews. 1994 Phylogenetic positions of novel aerobic bacteriochlorophyll $a$-containing bacteria and descriptions of Roseococcus thiosolfatophilus gen. nov., sp. nov., Erythromicrobium ramosum gen. nov., sp. nov., and Erythrobacter litoralis sp. nov. Int. J. Syst. Bacteriol. 44:427-434. 